\title{
Application Of Backpropagation Neural Networks In Predicting Rainfall Data In Ambon City
}

\author{
Y. A. Lesnussaa, ${ }^{1, *}$, C. G. Mustamua, ${ }^{2}$, F. Kondo Lembanga, ${ }^{3}$, , M. W. Talakuaa, ${ }^{4}$ \\ Mathematic Department, Pattimura University, Jl. Ir. M. Putuhena, Poka, 97233, Ambon-Indonesia \\ ${ }^{1}$ yopi_a_lesnussa@yahoo.com*; ${ }^{2}$ chelsea.gisella2015@gmail.com; \\ ${ }_{3}^{3}$ ferrykondolembang@gmail.com; ${ }^{4}$ ocat_14@yahoo.com \\ * corresponding author
}

ARTICLE INFO

Article history:

Received: 2018-03-01

Revised: 2018-05-04

Accepted: 2018-06-05

Keywords:

Artificial Neural Networks

Backpropagation

Rainfall prediction

\begin{abstract}
The Backpropagation algorithm is a method of multilayered Artificial Neural Networks. Backpropagation artificial neural networks can be applied in every area of human life; one of them is in prediction of weather. Artificial neural network can be used for predicting because of having the capability of examining and determining the historical data used for prediction. In this research, we have utilized Backpropagation artificial neural network to predict the rainfall in Ambon City. This research have used monthly rainfall data from 2011 to 2015 and several parameters to predict the rainfall such as: air temperature, air velocity and air pressure. The result shows accuracy level is $80 \%$ by using alpha 0.7 , iteration number (epoch) 10000 and MSE value is 0.022 . Therefore, the result of rainfall prediction system is accurate.
\end{abstract}

Copyright (C) 2017 International Journal of Artificial Intelligence Research. All rights reserved.

\section{Introduction}

In the reality, people often face various problems that require people to think and find new things that can facilitate them in solving the problem. Along with the development of science and technology, there are many methods for analyzing, classifying and visualizing certain objects that can provide benefits for human activities. With human intelligence, has created various technologies used in solving various problems in human life. One of them is Artificial Neural Network (ANN) [3]. ANN have been extensively used todays days in various aspects of science and engineering because of its ability to model both linear and non-linear systems without the need to make assumptions as are implicit in most traditional statistical approaches [38]. Artificial Neural Networks is an information processing system that has similar characteristics to biological neural networks in human life (Fig. 1). Neural network first introduced by Waffen McCulloch and Walter Pitts in 1943. By some experts, artificial neural networks have been developed as applications to solve problems in human life [3],[9].

Indonesia is a country passed by the equator and surrounded by two oceans and two continents. This position makes Indonesia as a region that has a variety of climate. Climate is a natural habit that is driven by a combination of several elements like solar radiation, temperature, humidity, rainfall, air temperature, air pressure and wind pressure. The elements are different from one place to another [12],[17]. 


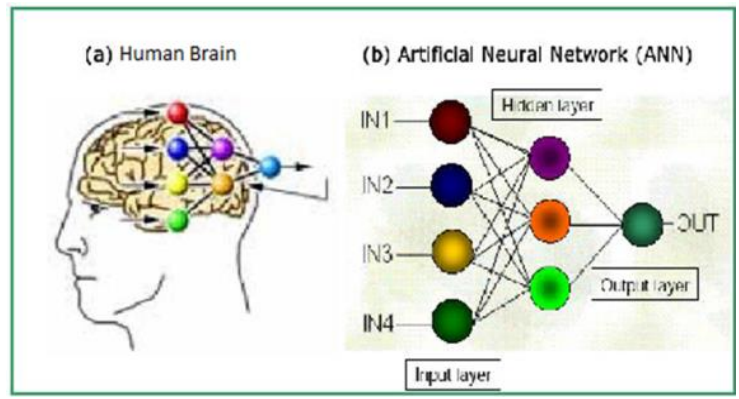

Fig. 1. The Artificial Neural Network has

The difference of weather or climate is due to altitude, latitude, pressure area, ocean currents, and soil surface. Rainfall plays very important role in human life and agriculture, it is very essential for irrigation and rainfall prediction is also useful for sewer management, water management, and flood forecasting [2]. However, too low or too high rainfall can cause disasters [43]. Climate change in the world gives many impacts on changing rainfall patterns. It needs a method that can predict rainfall based on rainfall patterns that occur after climate change. All the disaster can be anticipated with accurate information about how much rainfall will fall somewhere in a certain period of time [18].

Backpropagation is a supervised learning algorithm and is commonly used by Perceptron with multiple layers to change the weights associated with neurons in the hidden layer (Fig. 2 and Fig. 3). Backpropagation algorithm uses output error to change the value of the weights in the backward direction. To get error in this stage, forward propagation must be done first [3].

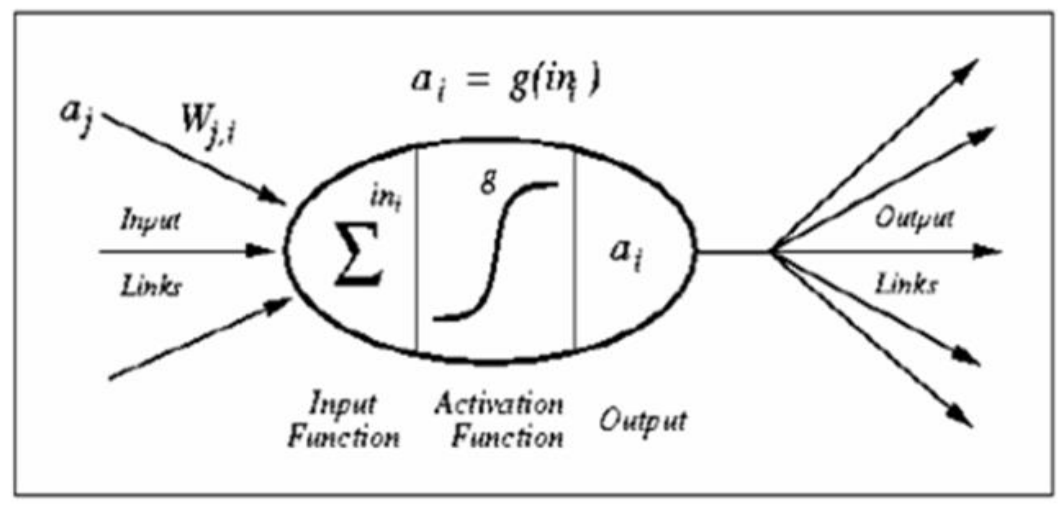

Fig. 2. The system of Artificial Neural Network (ANN)

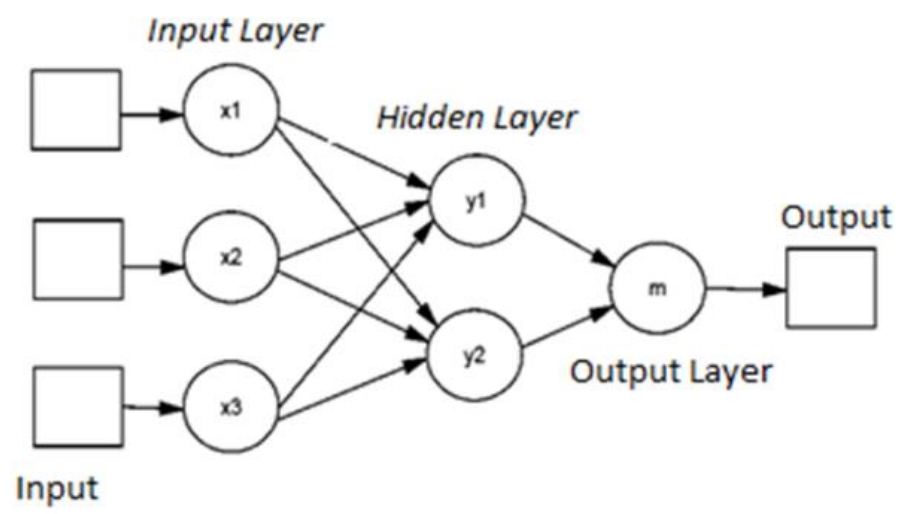

Fig. 3. The Architecture of Multilayer Artificial Neural Network (ANN) 


\section{Method}

research, such as: temperature, wind speed, and air pressure, rainfall. The data of Temperature, wind speed, air pressure and rainfall are obtained from Badan Meteorologi, Klimatologi, dan Geofisika $(B M K G)$ at Maluku Province. The data is a monthly data from 2011-2015.

\section{A. Technique of Analysis Data}

This research using Backpropagation method, so there are 2 stages such as: training data and testing data. Both of these stages of training and testing like the following flowchart in Fig. 4 and Fig. 5:

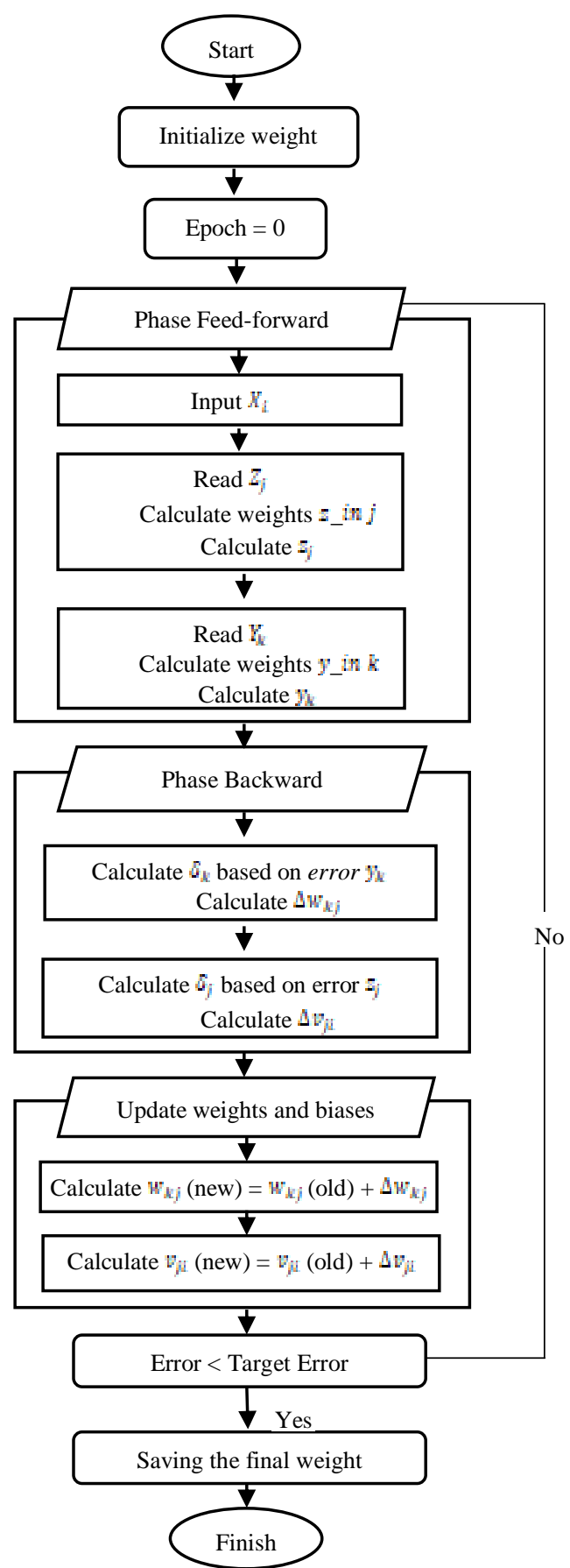

Fig. 4. Flowchart of training process on Back-propagation network 


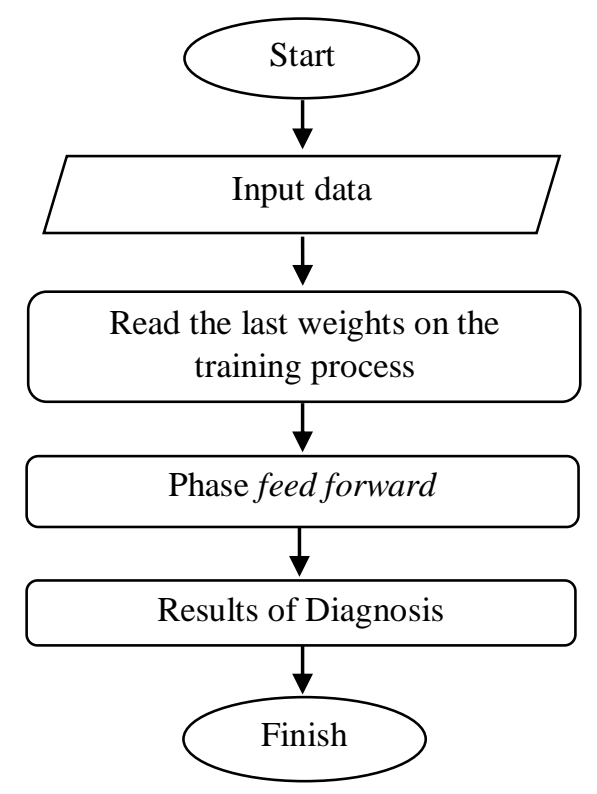

Fig. 5. The flow chart of the testing process of Back-propagation network

After training stage to obtain final weights, then the weights are used for the testing process (the detail algorithm or steps drawn by both flowchart in Fig. 4 and Fig. 5). The paper implements one of these applications by building training and testing data sets and finding the number of hidden neurons in these layers for the best performance [23]. All the data collected are separated into 2 parts of input and output are classified as sequential input data is as follows:

Air temperature as variable $\mathrm{X}_{1}$

Wind Speed as variable $\mathrm{X}_{2}$

Air Pressure as variable $\mathrm{X}_{3}$

Then the rainfall is classified as the desired output or target as variable $y$.

The number of data that used in this research is 60 ; consist of 45 data used as training data and 15 data used as testing data. In this research the desired output or target is rainfall with the patterns divided into 5 parts, as follows:

Pattern 1 for the value $b \leq 5$ with the condition very light rain

Pattern 2 for the value $6 \leq \mathrm{b} \leq 20$ with the condition light rain,

Pattern 3 for the value $21 \leq b \leq 50$ with the condition moderate rain,

Pattern 4 for the value $51 \leq \mathrm{b} \leq 100$ with the condition heavy rain, and

Pattern 5 for the value $b>100$ with the condition very heavy rain,

Information: $\mathrm{b}=$ rainfall.

\section{Result}

After defined the variables then the data will be analyze by using software MATLAB. By using this method must be done in 3 step of phase to have the rainfall output. These steps are training phase, testing phase and analysis or forecasting phase. To obtain the desired results it is necessary to determine the formation or pattern of input system, like the following:

1) Net Size: Input Layer: 3 neurons

Hidden Layer: 20 neuron 12 neuron 1 neuron 1 neuron and 1 neuron

Output Layer: 1 neuron 
Maximum epoch /iteration: 10000

Learning rate: 0,7

The training phase uses 45 data. From 45 training data obtained the following analysis. For each variation, the maximum number of iterations is similar. The number of iterations (epoch): 10000 . The detail result is presented in the following table:

Table 1. Result of data analysis

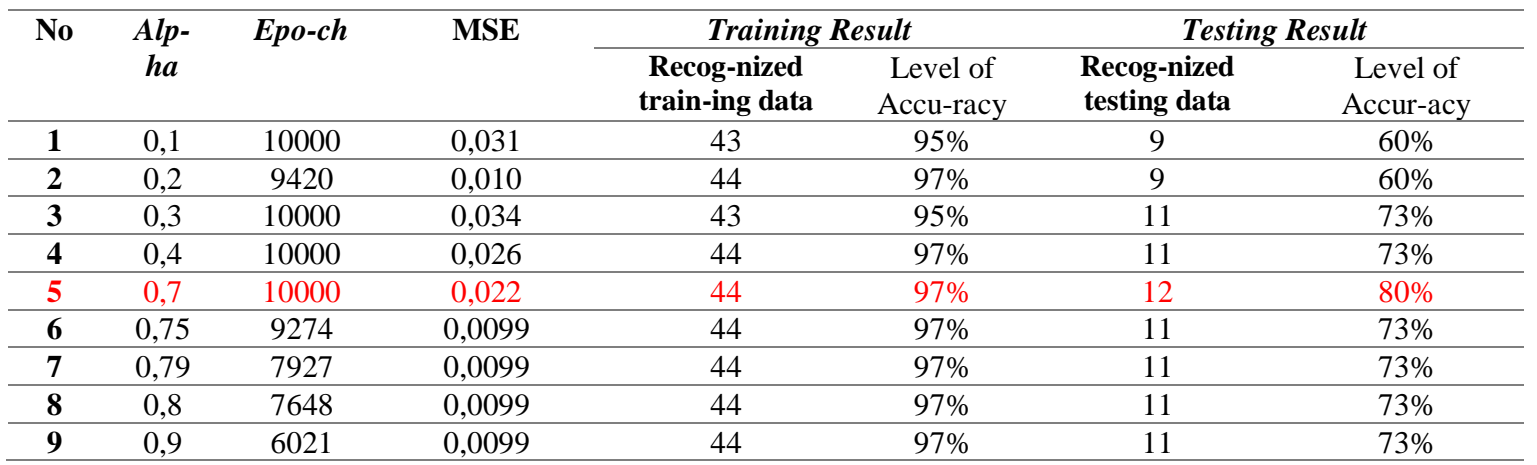

Based on Table 1 above, the best result in the training and testing process is at the time of learning rate 0.7 , with maximum iteration of 10000, the value of MSE 0.022 and the level accuracy of data is $97 \%$ for the training stage and for the testing stage is $80 \%$.

In the graph below, we will show the result of data analysis from learning rate $(\alpha) 0.7$. The comparison results between the target (o) and output (*) network, that can be observed by observing the placement of the output of the network $(*)$ position. If the network output $\left(^{*}\right)$ occupies the same position as the target (o) then the data analysis is said to be good. For more details information can be seen in Fig. 6, below:

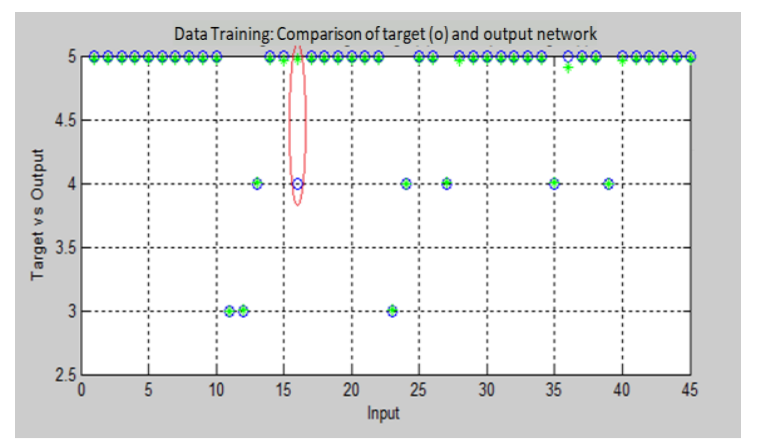

Fig. 6. Result graph of training with Alpha 0,7

In Figure 6, show that the comparison between the target (o) and output (*) of the network in the training data with alpha 0.7. It can be seen that most of the output network and target are close together (almost occupying the same position), where there are 44 of (o) and $(*)$ adjacent and only 1 of (o) and $\left(^{*}\right)$ on the $16^{\text {th }}$ data is far (in a red circle) therefore the result of training with alpha 0.7 is said to be good.

The following will present the results of the training on the comparison table between the expected target and outcome training targets that have been included in the grouping of predefined data patterns: 
Table 2. Grouping of Network Training Results

$\begin{array}{ll}\mathrm{n}^{\text {th }} \text { Data } & \begin{array}{l}\text { Output } \\ \text { Weight }\end{array}\end{array}$ Class Target Information

\begin{tabular}{lllll}
\hline $\mathbf{1}$ & 4.9762 & 5 & 5 & Match \\
\hline $\mathbf{2}$ & 4.9688 & 5 & 5 & Match \\
\hline $\mathbf{3}$ & 4.9767 & 5 & 5 & Match \\
\hline $\mathbf{4}$ & 4.9768 & 5 & 5 & Match \\
\hline $\mathbf{5}$ & 4.9767 & 5 & 5 & Match
\end{tabular}

\begin{tabular}{ccccl}
\hline $\mathbf{5}$ & 4.9767 & 5 & 5 & Match \\
\hline $\mathbf{6}$ & 4.9766 & 5 & 5 & Match \\
\hline $\mathbf{7}$ & 4.9766 & 5 & 5 & Match \\
\hline $\mathbf{8}$ & 4.9766 & 5 & 5 & Match \\
\hline $\mathbf{9}$ & 4.9765 & 5 & 5 & Match \\
\hline $\mathbf{1 0}$ & 4.9746 & 5 & 5 & Match \\
\hline
\end{tabular}

\begin{tabular}{lllll}
$\mathbf{1 0}$ & 4.9746 & 5 & 5 & Match \\
\hline $\mathbf{1 1}$ & 2.9993 & 3 & 3 & Match \\
\hline $\mathbf{1 2}$ & 3.0000 & 3 & 3 & Match \\
\hline $\mathbf{1 3}$ & 4.0056 & 4 & 4 & Match \\
\hline $\mathbf{1 4}$ & 4.9683 & 5 & 5 & Match
\end{tabular}

\begin{tabular}{llllc}
\hline $\mathbf{1 4}$ & 4.9683 & 5 & 5 & Match \\
\hline $\mathbf{1 5}$ & 4.9672 & 5 & 5 & Match \\
\hline $\mathbf{1 6}$ & 4.9747 & 5 & 4 & Not Match \\
\hline $\mathbf{1 7}$ & 4.9767 & 5 & 5 & Match \\
\hline $\mathbf{1 8}$ & 4.9766 & 5 & 5 & Match \\
\hline $\mathbf{1 9}$ & 4.9764 & 5 & 5 & Match
\end{tabular}

\begin{tabular}{lllll}
$\mathbf{1 8}$ & 4.9766 & 5 & 5 & Match \\
\hline $\mathbf{1 9}$ & 4.9764 & 5 & 5 & Match \\
\hline $\mathbf{2 0}$ & 4.9766 & 5 & 5 & Match \\
\hline $\mathbf{2 1}$ & 4.9764 & 5 & 5 & Match \\
\hline $\mathbf{2 2}$ & 4.9746 & 5 & 5 & Match
\end{tabular}

\begin{tabular}{lllll}
\hline $\mathbf{2 2}$ & 4.9746 & 5 & 5 & Match \\
\hline $\mathbf{2 3}$ & 3.0000 & 3 & 3 & Match \\
\hline $\mathbf{2 4}$ & 3.9997 & 4 & 4 & Match \\
\hline $\mathbf{2 5}$ & 4.9755 & 5 & 5 & Match \\
\hline $\mathbf{2 6}$ & 4.9745 & 5 & 5 & Match \\
\hline $\mathbf{2 7}$ & 4.0003 & 4 & 4 & Match \\
\hline $\mathbf{2 8}$ & 4.9657 & 5 & 5 & Match \\
\hline $\mathbf{2 9}$ & 4.9766 & 5 & 5 & Match \\
\hline $\mathbf{3 0}$ & 4.9763 & 5 & 5 & Match \\
\hline $\mathbf{3 1}$ & 4.9765 & 5 & 5 & Match \\
\hline $\mathbf{3 2}$ & 4.9766 & 5 & 5 & Match \\
\hline $\mathbf{3 3}$ & 4.9762 & 5 & 5 & Match \\
\hline $\mathbf{3 4}$ & 4.9693 & 5 & 5 & Match \\
\hline $\mathbf{3 6}$ & 4.0033 & 4 & 4 & Match \\
\hline $\mathbf{3 7}$ & 4.9074 & 5 & 5 & Match \\
\hline $\mathbf{3 8}$ & 4.9747 & 5 & 5 & Match \\
\hline $\mathbf{3 9}$ & 3.9997 & 4 & 4 & Match \\
\hline $\mathbf{4 0}$ & 4.9649 & 5 & 5 & Match \\
\hline $\mathbf{4 1}$ & 4.9763 & 5 & 5 & Match \\
\hline $\mathbf{4 2}$ & 4.9767 & 5 & 5 & Match \\
\hline $\mathbf{4 3}$ & 4.9760 & 5 & 5 & Match \\
\hline $\mathbf{4 5}$ & 4.9750 & 5 & 5 & Match \\
\hline & 4.9762 & 5 & 5 & Match \\
\hline
\end{tabular}

After the training phase, then the next phase is testing to determine the results of rainfall prediction of target data and network output. The following (Fig. 7) is presented the graph with Alpha testing 0.7 . 


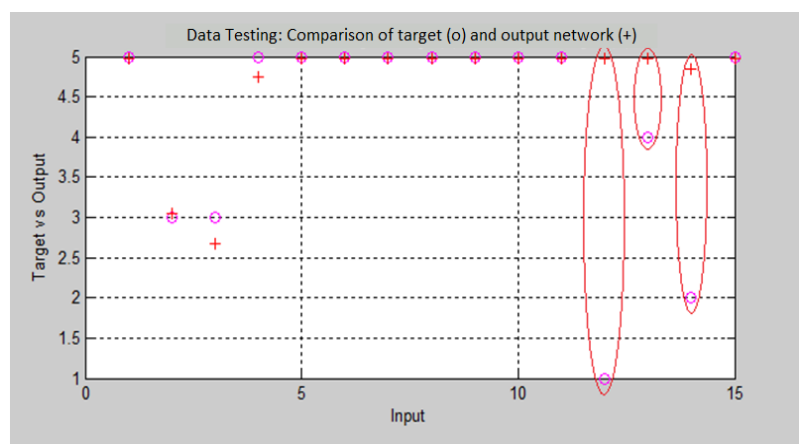

Fig. 7. Result graph of testing with Alpha 0,7

In Fig. 7, shows that the comparison between the target (o) with the network output (+) in training data with Alpha 0,7. At the testing phase the number of data is 15 , by 12 data targets (o) and the output $(+)$ is close together (almost occupying the same position) and 3 other data are far apart (in red circle). So it can be said that the testing results between training data and targets can be quite good in predicting rainfall.

The following Table 3, will present the testing results between the expected target and the output target results that have been included in the grouping of predefined data patterns:

Table 3. Grouping of network test results

\begin{tabular}{ccccc}
\hline $\begin{array}{c}\mathbf{n}^{\text {th }} \\
\text { Data }\end{array}$ & $\begin{array}{c}\text { Output } \\
\text { Weight }\end{array}$ & Class & Target & $\begin{array}{c}\text { Inform- } \\
\text { ation }\end{array}$ \\
\hline $\mathbf{1}$ & 4.9754 & 5 & 5 & right \\
\hline $\mathbf{2}$ & 3.0452 & 3 & 3 & right \\
\hline $\mathbf{3}$ & 2.6672 & 3 & 3 & right \\
\hline $\mathbf{4}$ & 4.7514 & 5 & 5 & right \\
\hline $\mathbf{5}$ & 4.9762 & 5 & 5 & right \\
\hline $\mathbf{6}$ & 4.9759 & 5 & 5 & right \\
\hline $\mathbf{7}$ & 4.9750 & 5 & 5 & right \\
\hline $\mathbf{8}$ & 4.9760 & 5 & 5 & right \\
\hline $\mathbf{9}$ & 4.9766 & 5 & 5 & right \\
\hline $\mathbf{1 0}$ & 4.9764 & 5 & 5 & right \\
\hline $\mathbf{1 1}$ & 4.9765 & 5 & 5 & right \\
\hline $\mathbf{1 2}$ & 4.9762 & 5 & 1 & wrong \\
\hline $\mathbf{1 3}$ & 4.9762 & 5 & 4 & wrong \\
\hline $\mathbf{1 4}$ & 4.8502 & 5 & 2 & wrong \\
\hline $\mathbf{1 5}$ & 4.9726 & 5 & 5 & right \\
\hline
\end{tabular}

The results obtained from this research can be explained that to predict the rainfall can't be measured as a whole only by using rainfall data but also can use other data that influence the state of rainfall. This is seen from the level of accuracy of forecasting results at the training stage $97 \%$ and $80 \%$ testing stage that causes the forecasting results are said to be good.

\section{Conclusion}

From the results of rainfall forecasting using Back-propagation Artificial Neural Network, it can be obtained that the accuracy level of rainfall prediction is $80 \%$, by using alpha 0.7 , epoch 10000 and MSE value is 0.022 . Therefore, it can be concluded that the Backpropagation neural networks show the best result and accurate in forecasting rainfall data both in training and testing phase. 


\section{References}

[1] A. Buono, A. Kurniawan, A. Faqih, Peramalan Awal Musim Hujan Menggunakan Jaringan Syaraf Tiruan Backpropagation Levenberg-Marquadrat (Early Forecasting Rainy Season Using Artificial Neural Network Backpropagation Levenberg-Marquadrat), Semin. Nas. Apl. Teknol. Inf. 2012 (SNATI 2012), No. 6, pp. 27-32, 2012.

[2] A. Chaturvedi, Rainfall Prediction using Backpropagation Feed Forward Network, International Journal of Computer Applications, Vol. 119 (4), pp. 1-5, 2015

[3] A. Hermawan, Jaringan Syaraf Tiruan dan Aplikasinya (Artificial Neural Network and its Applications). Yogyakarta : Andi, 2006.

[4] A. Y. Shamseldin, Application of a Neural Network Technique to Rainfall-Runoff Modelling, Journal of Hydrology, Vol. 199, pp. 272-294, 1997.

[5] A. W. Minns, M. J. Hall, Artificial Neural Networks as Rainfall-Runoff Models, Hydrological Sciences Journal, Vol. 41(3), pp. 399-417, 1996.

[6] C. Oktaviani \& Afdal, Prediksi Curah Hujan Bulanan Menggunakan Jaringan Syaraf Tiruan Dengan Beberapa Fungsi Pelatihan Backpropagation, 2013.

[7] C. W. Dawson, R. Wilby, An Artificial Neural Network Approach to Rainfall-Runoff Modelling, Hydrological Sciences Journal, Vol. 43(1), pp. 47-66, 1998.

[8] C. Venkatesan, S. D. Raskar, S. S. Tambe, B. D. Kulkarni, R. N. Keshavamurty, Prediction of all India Summer Monsoon Rainfall Using Error Back-propagation Neural Networks, Meteorology and Atmospheric Physic, Vol. 62(3-4), pp. 225-240, 1997.

[9] D. Puspitaningrum, Pengantar Jaringan Syaraf Tiruan (Introduction to Artificial Neural Network), Andi, Yogyakarta, 2006.

[10]D. Tsintikidis, J. L. Haferman, E. N. Anagnostou, W. F. Krajewski, T. F. Smith, A Neural Network Approach to Estimating Rainfall from Spaceborne Microwave Data, IEEE Transactions on Geoscience and Remote Sensing, Vol. 35(5), pp. 1079-1093, 1997.

[11]DR. Nayak, A. Mahapatra, P. Mishra., A Survey on Rainfall Prediction Using Artificial Neural Network, Intternational Journal of Comput. Appl, Vol. 72(16), pp. 32-40, 2013.

[12]E. Aldrian, et al., Adaptasi dan Mitigasi Perubahan Iklim di Indonesia, Pusat Perubahan Iklim dan Kualitas Udara Kedeputian Bidang Klimatologi, Badan Meteorologi, Klimatologi dan Geofisika. Jakarta, 2011.

[13]E. Vamsidhar, K.V.S.R.P. Varma, P.S. Rao, R. Satapati, Prediction of Rainfall Using Backpropagation Neural Network Model, International Journal on Computer Science and Engineering, Vol. 2(4), pp. 1119-1121, 2010.

[14] G. Geetha, R. S. Selvaraj, Prediction of Monthly Rainfall in Chennai Using Backpropagation Neural Network, Int. Journal of Eng. Sci. Technol., Vol. 3(1), pp. 1994-1996, 2011.

[15]H. R. Maier, G. C. Dandy, The Use of Artificial Neural Networks for the Prediction of Water Quality Parameters, Water Resources Research, Vol. 32(4), pp. 1013, 1996

[16] I. Andi, Metode Jaringan Saraf Tiruan Propagasi Balik Untuk Estimasi Curah Hujan Bulanan di Ketapang Kalimantan Barat, Lampung, 2013.

[17] I. Juaeni, Analisis Variabilitas Curah Hujan Wilayah Indonesia Berdasarkan Pengamatan Tahun 19752004, Lembaga Penerbangan dan Antariksa Nasional, 2007.

[18] I. Wahyuni, N. R. Adam, W. F. Mahmudy, A. Iriany, Modelling Backpropagation Neural Network for Rainfall Prediction in Tengger East Java, Proceeding of International Conference on Sustainable Information Engineering and Technology (SIET), Malang, Indonesia, 2017.

[19]I. Wahyuni, W. F. Mahmudy, Rainfall Prediction in Tengger-Indonesia Using Hybrid Tsukamoto FIS and Genetic Algorithm, J. ICT Res. Appl., Vol. 11(1), pp.38-54, 2017.

[20] J. J. Siang., Jaringan Syaraf Tiruan dan Pemrogramannya Menggunakan Matlab (Artificial Neural Network and its Programme Using Matlab), Yogyakarta: Andi, 2005.

[21] J. Smith, R. N. Eli, Neural Network Models of Rainfall-Runoff Processes, Journal of Water Resources Planning and Management, Vol. 121(6), pp. 499-508, 1995.

[22] K. R. Ku-Mahmud,Y. Yusof, T. B. Wei., Neural Network Modelling for Predicting Rainfall Level, IFAC Artificial Intelligence in Agriculture, pp. 49-53, Budapest, Hungary, 2001.

[23] K. Abhisek, A. Kumar, R. Ranjan, S. Kumar, A Rainfall Prediction Model Using Artificial Neural Network, IEEE Conference of Control and System Graduate Research Colloquium (ICSGRC), Selangor, Malaysia, 2012 
[24] K. Govinda, S. Hiremath, Rainfall Prediction Using Neural Networks, Int. Journal Appl. Eng. Res., Vol 9(23):21243-21254, 2014.

[25] K. L. Hsu, H. V. Gupta, S. Sorooshian, Artificial Neural Network Modelling of the Rainfall-Rainoff Process, Water Resources Research, Vol. 31(10), pp. 2517-2530, 1995.

[26] MCV. Ramirez, NJ. Ferreira, HF. Velho, Artificial Neural Network Technique for Rainfall Forecasting Applied to the Sa o Paulo Region, J. Hydrol, 301:146-162, 2005.

[27] Mislan, Haviluddin, S. Hardwinarto, Sumaryono, M. Aipassa, Rainfall Monthly Prediction Based on Artificial Neural Network: A Case Study in Tenggarong Station, East Kalimantan-Indonesia, Procedia Computer Science 59, pp. 142-151, 2015.

[28] M. Lorrai, G. M. Sechi, Neural Nets for Modelling Rainfall-Runoff Transformations, Water Resources Management, Vol. 9(4), pp. 299-313, 1995.

[29] M. N. French, W. F. Krajewski, R. R. Cuykendall, Rainfall Forecasting in Space and Time Using a Neural Network, Journal of Hydrology 137, pp. 1-37, 1992.

[30] N. Khalili, Rainfall Prediction Using Artificial Neural Network, M.s. thesis, Ferdowsi Univ. of Mashhad, Iran, 2006.

[31] N. Khalili, S. R. Khodashenas, K. Davary, M. M. Baygi, F. Karimaldini, Prediction of Rainfall Using Artificial Neural Networks for Synoptic Station of Mashhad: a case study, Arabian Journal of Geosciences, 2016.

[32] NQ. Hung, MS Babel S. Weesakul, NK Tripathi, An Artificial Neural Network Model for Rainfall Forecasting in Bangkok Thailand, Hydrol Earth Syst Sci, Vol. 5, 183-218, 2009.

[33] O. Kisi, Stream Flow Forecasting Using Different Artificial Neural Network Algorithms, J. Hydrol. Eng. (ASCE), 12:5(532), 532-539, 2007.

[34]P. Singh, B. Borah, Indian Summer Monsoon Rainfall Prediction Using Artificial Neural Network, Stoch. Environ. Res. Risk Asess., 27:1585-1599, 2013.

[35] R. D. Braddock, M. L. Kremmer, L. Sanzogni, Feed Forward Artificial Neural Network Model for Forecasting Rainfall Run-Off, Proceedings of the International Congress on Modelling and Simulation (Modsim 97), The Modelling and Simulation Society of Australia Inc., Hobart, Australia, pp. 1653-1658, 1997.

[36] R. Golob, T. Stokelj, D. Grgic, Neural Network Based Water Inflow Forecasting, Control Engineering Practice, Vol. 6(5), pp. 593-600, 1998.

[37] R. J. Kuligowski, A. P. Barros, Using Artificial Neural Networks to Estimate Missing Rainfall Data, Journal of the American Water Resources Association, Vol. 34(6), pp. 1437-1447, 1998.

[38] S. Lee, S. Cho, P. M. Wong, Rainfall Prediction Using Artificial Neural Network, J. Geog. Inf. Decision Anal. 2, 233-242, 1998.

[39] S. Michaelide, Classification of Rainfall Variability By Using Artificial Neural Network, Int. Journal of Climatol., 21:1401-1414, 2001.

[40] SK. Nanda, DP. Tripathy, SK. Nayak, S. Mohapatra, Prediction of Rainfall in India Using Artificial Neural Network (ANN) Models, International Journal of Intel. Syst. Appl. 12:1-22, 2013.

[41] S. S. Baboo, I. K. Shareef, An Efficient Weather Forecasting Model Using Artificial Neural Network, Int. J. Environ. Scien. \& Develop., Vol. 1(4), pp. 1119-1121, 2010.

[42] S. Sureerattman, H. N. Phien, Back-propagation Network for Daily Streamflow Forecasting, Water Resources Journal, pp. 1-7, 1997.

[43] Tjasyono, Klimatologi Umum (Generel Climatology), ITB, Bandung, 2006.

[44] T. Hill, L. Marquez, M. O’Connor, W. Remus, Artificial Neural Network Models for Forecasting and Decision Making, International Journal of Forecasting, Vol. 10, pp. 5-15, 1994. 